\title{
EXTENDED TABLE OF CONTENTS
}

About the authors

$x i$

Preface

Table of cases

$\mathrm{xv}$

Table of legislation

xviii

1. A PRIMER ON CORPORATE GOVERNANCE IN BANKS AND FINANCIAL INSTITUTIONS: ARE BANKS SPECIAL?

\section{Andreas Kokkinis}

1. INTRODUCTION

A. Agency theory: Aligning the interests of managers and shareholders $\quad 1.05$

i. A brief overview of agency theory $\quad 1.05$

ii. Agency costs and risk-taking by companies

2. THE FAILURE OF CONVENTIONAL CORPORATE GOVERNANCE IN THE CASE OF BANKS: PROFIT MAXIMISATION $V$ THE PUBLIC INTEREST
A. The public interest in financial stability
i. The economic significance of banks
ii. The unique business risks faced by banks
iii. Systemic risk
iv. The peculiar capital structure of banks
B. The misalignment between the interests of bank shareholders and the public interest

3. THE LIMITED POTENTIAL OF SHAREHOLDERS AND CREDITORS TO MONITOR RISK TAKING BY BANKS

A. The limits of shareholder governance of risk taking by banks $\quad 1.39$

i. The opacity of banks' assets $\quad 1.40$

ii. The effect of asset opacity on risk-monitoring by bank shareholders $\quad 1.45$

B. The limits of bondholder monitoring of risk taking by banks $\quad 1.48$

C. The very limited risk-monitoring by depositors $\quad 1.56$

4. THE EFFECT OF BANK OPACITY ON THE CORE PROBLEM OF THE MISALIGNMENT BETWEEN THE PUBLIC INTEREST AND CONVENTIONAL CORPORATE GOVERNANCE $\quad 1.60$

5. TOWARDS A REGULATORY APPROACH TO BANK CORPORATE GOVERNANCE $\quad 1.65$
A. The recent regulatory interventions to bank corporate governance
B. A broader reconceptualisation of bank corporate governance

6. CONCLUSION

\section{CORPORATE GOVERNANCE AND BANKS: THE ROLE AND} COMPOSITION OF THE BOARD

\section{Edward Walker-Arnott}

1. COMPANY LAW AND THE BOARD

2. THE CORPORATE GOVERNANCE CODE

3. THE APPROVED PERSONS REGIME

4. BANKS AND FINANCIAL INSTITUTIONS
A. Royal Bank of Scotland
B. Halifax Bank of Scotland
C. Barclays plc
D. Parliamentary Commission on Banking Standards 
i. Regulatory oversight of boards $\quad 2.57$

ii. Comments and suggestions $\quad 2.61$

iii. The Financial Services (Banking Reform) Act 2013

5. THE FUTURE

3. DIRECTORS' DUTIES AND LIABILITIES: DISQUALIFYING 'UNFIT' DIRECTORS AT BANKS? POLITICAL RHETORIC AND THE DIRECTORS' DISQUALIFICATION REGIME

John Lowry and Rod Edmunds

$\begin{array}{lll}\text { 1. INTRODUCTION } & 3.01 \\ \text { 2. THE RISE AND FALL OF THE ROYAL BANK OF SCOTLAND } & 3.07 \\ \text { 3. HBOS: 'AN ACCIDENT WAITING TO HAPPEN' } & 3.13 \\ \text { 4. THE COMPANY DIRECTORS DISQUALIFICATION ACT 1986 } & 3.16 \\ \text { 5. DETERMINING UNFITNESS TO BE CONCERNED IN THE MANAGEMENT OF A COMPANY } & 3.19 \\ \text { 6. INDIVIDUAL FAILURE AND ENSURING PERSONAL RESPONSIBILITY: OLD WINE IN NEW } & \\ \text { BOTTLES } & 3.23 \\ \text { 7. CONCLUUSION } & 3.27\end{array}$

4. THE ROLE OF INSTITUTIONAL SHAREHOLDERS: STEWARDSHIP AND THE LONG-/SHORT-TERM DEBATE

Arad Reisberg

1. INTRODUCTION

A. Background $\quad 4.01$

B. Short-termism - human nature and culture $\quad 4.02$

C. Major reports, consultations and papers on the topic since $2010 \quad 4.04$

2. SHORT-TERM V LONG-TERM DICHOTOMY AND THE ELUSIVENESS OF THE TERM

A. Do we all mean the same thing? How long is 'long-term'? 4.06

3. WHAT'S THE PROBLEM WITH SHORT-TERMISM? $\quad 4.10$

4. THE CAUSES OF SHORT-TERMISM $\quad 4.20$

5. ADDITIONAL DRIVERS OF SHORT-TERMISM 4.26

A. Driver no. 1: Does frequent periodic financial reporting cause short-termism? $\quad 4.27$

$\begin{array}{ll}\text { B. Driver no. 2: Shareholders' disengagement } & 4.31\end{array}$

C. Driver no. 3: Diverse incentives $\quad 4.38$

6. HOW TO BREAK THE SHORT-TERM CYCLE $\quad 4.39$

$\begin{array}{lr}\text { A. Tax reforms } & 4.40\end{array}$

B. Corporate governance modifications $\quad 4.41$

C. UK Government sets out steps to change culture in UK equity markets $\quad 4.42$

D. Are these steps in the right direction?

7. DEBATE IS FAR FROM OVER $\quad 4.47$

8. LOOKING AHEAD $\quad 4.55$

\section{DESIGN AND CONTROL OF REMUNERATION IN UK BANKS}

Marc TMoore

1. INTRODUCTION

2. PRINCIPAL FORMS OF DIRECTORIAL AND EXECUTIVE REMUNERATION

A. Basic director's service fee $\quad 5.03$

B. Executive salary $\quad 5.04$

C. Bonus payments $\quad 5.05$

D. Shares and restricted share grants $\quad 5.06$

E. Executive share options $\quad 5.08$

F. Pension allowance $\quad 5.10$

G. Gratuities $\quad 5.11$

H. Expenses and perquisites $\quad 5.12$

3. WHO DETERMINES DIRECTORS' REMUNERATION?

A. Fundamental principles $\quad 5.13$

$\begin{array}{ll}\text { B. The (limited) role of the courts } & 5.15\end{array}$ 
C. Remuneration committees $\quad 5.20$

D. Determination of non-executive directors' (NEDs') remuneration $\quad 5.24$

E. Directors' service contracts open for inspection by shareholders $\quad 5.25$

4. THE DIRECTORS' REMUNERATION REPORT AND 'SAY ON PAY' VOTE
A. Background
5.26
B. The new (post-2013) two-tier procedure for 'say on pay' voting 5.28
C. Expected impact of the 2013 reforms $\quad 5.32$

5. ALIGNING PAY WITH PERFORMANCE AND RISK TOLERANCE: THE REGULATORY FRAMEWORK APPLICABLE TO BANKS
A. Introduction $\quad 5.36$
B. Fundamental principles $\quad 5.38$
C. Bonus payments $\quad 5.41$
D. Long-term incentive schemes (executive share options and restricted share grants) 5.49
E. Severance payments ('golden parachutes') and pension allowances 5.52
F. Clawback and unilateral pay-reduction provisions $\quad 5.56$

\section{CORPORATE GOVERNANCE AND RISK MANAGEMENT IN BANKS AND FINANCIAL INSTITUTIONS}

Iris $\mathrm{H}-\mathrm{YChiu}$

1. INTRODUCTION

6.01

2. CORPORATE GOVERNANCE AS A FRAMEWORK FOR RISK MANAGEMENT

3. POST-CRISIS REGULATORY REFORMS IN CORPORATE GOVERNANCE AND RISK MANAGEMENT

6.06

CAN REGULATING RISK MANAGEMENT EFFECTIVELY SECURE RISK-TAKING AT OPTIMAL LEVELS?

5. CONCLUSION

7. CORPORATE REPORTING AND THE ACCOUNTABILITY OF BANKS AND FINANCIAL INSTITUTIONS

Iris $\mathrm{H}$-YChiu

1. INTRODUCTION

2. FINANCIAL REPORTING BY BANKS AND FINANCIAL INSTITUTIONS

3. THE RISE IN THE IMPORTANCE OF NARRATIVE REPORTING $\quad 7.20$

4. THE AUDIT COMMITTEE $\quad 7.39$

5. THE ROLE OF AUDITORS $\quad 7.45$

6. REGULATORY ACCOUNTABILITY, MICROPRUDENTIAL REPORTING AND REGULATORY SUPERVISION

7. CORPORATE TRANSPARENCY IN ESG MATTERS, SUSTAINABILITY AND INTEGRATED REPORTING

8. CONCLUSION

\section{SYSTEMS AND CONTROLS IN ANTI-BRIBERY AND CORRUPTION}

\section{Anna PDonovan}

1 INTRODUCTION

2. THE BRIBERY ACT 2010: A CATALYST FOR INTERNAL CONTROLS 8.06
A. Failure of commercial organisations to prevent bribery

B. The adequate procedures defence

3. THE BRIBERY ACT 2010: THE MOJ GUIDANCE

A. Principle 1: Proportionate procedures

B. Principle 2: Top-level commitment

C. Principle 3: Risk assessment

D. Principle 4: Due diligence

E. Principle 5: Communication (including training)

F. Principle 6: Monitoring and review

4. CULTURE AS A BULWARK AGAINST CORRUPTION?

A. Identifying culture's functionality

i. Culture as a normative ordering mechanism 
ii. Culture as a panacea $\quad 8.74$

iii. Culture as a social order $\quad 8.77$

B. Implementing culture $\quad 8.80$

i. Tone from the top $\quad 8.82$

ii. Communication $\quad 8.87$

iii. Employee participation $\quad 8.90$

iv. Enforcement $\quad 8.92$

5. CONCLUSION

ANNEX 8.1: SUMMARY OF KEY INTERNATIONAL CONVENTIONS

A. OECD Convention on Combating Bribery of Foreign Public Officials in International Business Transactions (the OECD Convention) 8.100

B. United Nations Convention Against Corruption (UNCAC) 8.104

C. Council of Europe and the Group of States Against Corruption (GRECO) 8.107

ANNEX 8.2: THE BRIBERY ACT 2010: CORPORATE HOSPITALITY AND FACILITATION
PAYMENTS

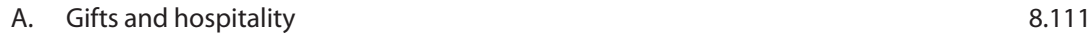

B. Facilitation payments $\quad 8.118$

9. THE MARKET FOR CORPORATE CONTROL IN THE BANKING INDUSTRY

Georgina Tsagas

1. INTRODUCTION

9.01

2. RECENT DEVELOPMENTS 9.05

3. BANK ACQUISITION CASE STUDIES 9.09

A. ABN AMRO and Banca Antonveneta $\quad 9.10$

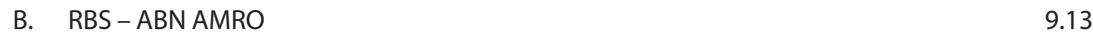

C. BNP - Société Générale $\quad 9.20$

4. LEGAL FRAMEWORK $\quad 9.22$

A. The Qualifying Holdings Directive $\quad 9.24$

B. The UK Takeover Code $\quad 9.36$

C. EU Takeover Directive $\quad 9.45$

5. THE MARKET FOR CORPORATE CONTROL IN THE BANKING SECTOR 9.47

6. THE MARKET FOR CORPORATE CONTROL IN THE BANK SECTOR ASSESSED 9.53

A. The role of the supervisory authority $\quad 9.54$

B. The role of the board of the bidding company 9.59

C. The role of the target board and target shareholders 9.64

$\begin{array}{ll}\text { 7. CONCLUSION } & 9.67\end{array}$

$\begin{array}{ll}\text { Index } & 337\end{array}$ 